\title{
Holocene history of a lake filling and vegetation dynamics of the Serra Sul dos Carajás, southeast Amazonia
}

\author{
JOSÉ T.F. GUIMARÃES ${ }^{1}$, PRAFULLA K. SAHOO ${ }^{1}$, PEDRO W.M. SOUZA-FILHO ${ }^{1,2}$, MARIANA M.J. \\ COSTA DE FIGUEIREDO ${ }^{1}$, LUIZA S. REIS ${ }^{1,4}$, MARCIO S. DA SILVA ${ }^{1}$ and TARCÍSIO M. RODRIGUES ${ }^{3}$ \\ ${ }^{1}$ Instituto Tecnológico Vale, Rua Boaventura da Silva, 955, Nazaré, 66055-090 Belém, PA, Brazil \\ ${ }^{2}$ Universidade Federal do Pará, Instituto de Geociências, Programa de Pós-graduação em Geologia \\ e Geoquímica, Av. Augusto Correa, 1, Guamá, 66075-110 Belém, PA, Brazil \\ ${ }^{3}$ Gerência de Meio Ambiente - Minas de Carajás, Departamento de Ferrosos Norte, Estrada \\ Raymundo Mascarenhas, s/n, Mina de N4, 68516-000 Parauapebas, PA, Brazil \\ ${ }^{4}$ Centro de Energia Nuclear na Agricultura, Av. Centenário, 303, São Dimas, 13400-000 Piracicaba, SP, Brazil \\ Manuscript received on December 28, 2016; accepted for publication on March 21, 2017
}

\begin{abstract}
How to cite: GUIMARÃES JTF, SAHOO PK, SOUZA-FILHO PWM, FIGUEIREDO MMJC, REIS LS, SILVA MS AND RODRIGUES TM. 2019. Holocene history of a lake filling and vegetation dynamics of the Serra Sul dos Carajás, southeast Amazonia. An Acad Bras Cienc 91: e20160916. DOI 10.1590/0001-3765201720160916.
\end{abstract}

\begin{abstract}
Down-core changes in sedimentary facies, elemental geochemistry, pollen, spore, $\delta 13 \mathrm{C}, \delta 15 \mathrm{~N}$ and radiocarbon records from a filled lake, named R4, of the Serra Sul dos Carajás were used to study the relationship between the paleomorphological and paleoecological processes and their significance for Holocene paleoclimatology of the southeast Amazonia. The sediment deposition of the R4 lake started around $9500 \mathrm{cal}$ yr BP. Increase of detrital components from 9500 to 7000 cal yr BP suggests high weathering of surrounding catchment rocks and soils, and deposition into the lake basin under mudflows. At that time, montane savanna and forest formation were already established suggesting predominance of wet climate. However, from 7000 to 3000 cal yr BP, a decline of detrital input occurred. Also, forest formation and pteridophytes were declined, while palms and macrophytes were remained relatively stable, indicating that water levels of the lake is likely dropped allowing the development of plants adapted to subaerial condition under drier climate conditions. After $3000 \mathrm{cal}$ yr BP, eutrophication and low accommodation space lead to high lake productivity and the final stage of the lake filling respectively, and forest formation may has acquired its current structure, which suggests return of wetter climate conditions.
\end{abstract}

Key words: Amazon Forest, canga vegetation, palynology, carbon and nitrogen isotopes, geochemistry.

\section{INTRODUCTION}

Incoming insolation has been considered as the main rule controlling the intensity of the South

Correspondence to: José Tasso Felix Guimarães

E-mail: tasso.guimaraes@itv.org

ORCid: https://orcid.org/0000-0002-9847-425X

* Contribution to the centenary of the Brazilian Academy of Sciences.
American monsoon system (SAMS) (Kutzbach et al. 2008), with precession regulating insolation changes at tropical latitudes and eccentricity modulating its amplitude (Berger 1978, Baker and Fritz 2015). Several paleoclimate records have been demonstrated the influence of precession on precipitation changes along the SAMS domain (e.g. Cruz et al. 2005, Wang et al. 2006, Cheng 
et al. 2013, Prado et al. 2013b). Absolute-dated speleothem oxygen isotope records from Cheng et al. (2013) were used to characterize climate changes in western and eastern Amazonia over the past 250,000 and 20,000 yr BP. Therefore, the data from eastern Amazonia indicated substantially wet conditions during the early-mid Holocene ( 10,000-5000 yr BP). In contrast, western Amazon records moderately dry conditions for this period. This suggests the presence of a dipole of precipitation associated to a walker cell that gives rise to an east-west bipolar see-saw pattern of monsoon precipitation (Cruz et al. 2009). However, Baker and Fritz (2015) re-evaluated the speleothem records presented by Cheng et al. (2013), and indicated different paleoclimate condition. Therefore, this new evidence needs to be tested using other paleoclimate proxies.

Several pollen and isotopic records in Amazonia suggest that during the early midHolocene the forested areas contracted, probably in response to a drier climate. During the late Holocene, arboreal vegetation became more prominent due to the return of wetter climate, most likely similar to those prevailing today (Pessenda et al. 1998, Behling and Costa 2000, Freitas et al. 2001, Bush et al. 2007, Mayle and Power 2008, Guimarães et al. 2012, 2013). The upland lakes of the Serra dos Carajás, southeast Amazonia, also registered this drier period, as indicated by the lower lake levels based on low detrital input into the lake basins associated with enrichment of $\mathrm{Hg}$, Se, organic carbon and evaporite minerals (Sifeddine et al. 2001, Cordeiro et al. 2008, Turcq et al. 2002, Guimarães et al. 2016). However, the development of interproxy studies integrating faciology and geochemistry with palynology are still needed for this region, and they are required to better understanding of the relationship between the morphological processes and paleovegetation patterns and their significance in terms of Holocene climate changes.

This works aims to study the Holocene history of a lake filling and vegetation changes in the Serra Sul dos Carajás considering the geomorphologic and paleoclimate changes using sedimentary facies, geochemical proxies (based on both major and trace elements), pollen, spore, $\delta^{13} \mathrm{C}, \delta^{15} \mathrm{~N}$ and radiocarbon data.

\section{STUDY SITE}

The study area is located in the Serra Sul of Carajás (Southern Plateau) in the domains of the Carajás National Forest, southeast Amazonia (Fig 1a). The plateau has altitude of around 730 $\mathrm{m}$ above mean sea level, rising above a forested landscape (i.e. open and dense ombrophilous; Fig. 1b). This region represents the major Archean tectonic province of the Amazonian craton (Macambira and Lafon 1995, Rämö et al. 2002), including low-grade mafic, intermediate and felsic metavolcanic rocks of the Parauapebas Formation and banded iron formations (BIFs) of the Carajás Formation (Olszewski et al. 1989). Extensive lateritic crusts developed over BIFs under a tropical humid climate. Several lakes developed over the crusts into closed-catchment systems occur in the surface of the plateau and formed by structural and degradation process of the lateritic profile (Maurity and Kotschoubey 1995). The studied lake of this work represents an inactive/filled lake, named R4 (Fig. 1b, c).

The dominant vegetation types of Carajás are dense and open ombrophilous forest that covers all lithologies except BIFs and in the study area occurs along the slopes of the plateau whereas montane savanna vegetation is developed over the lateritic crusts under edaphic conditions (Fig. 1b). The occurrence of extensive lateritic crusts and low water retention allowed the widespread development of plant species adapted to nutrient and hydric stress 

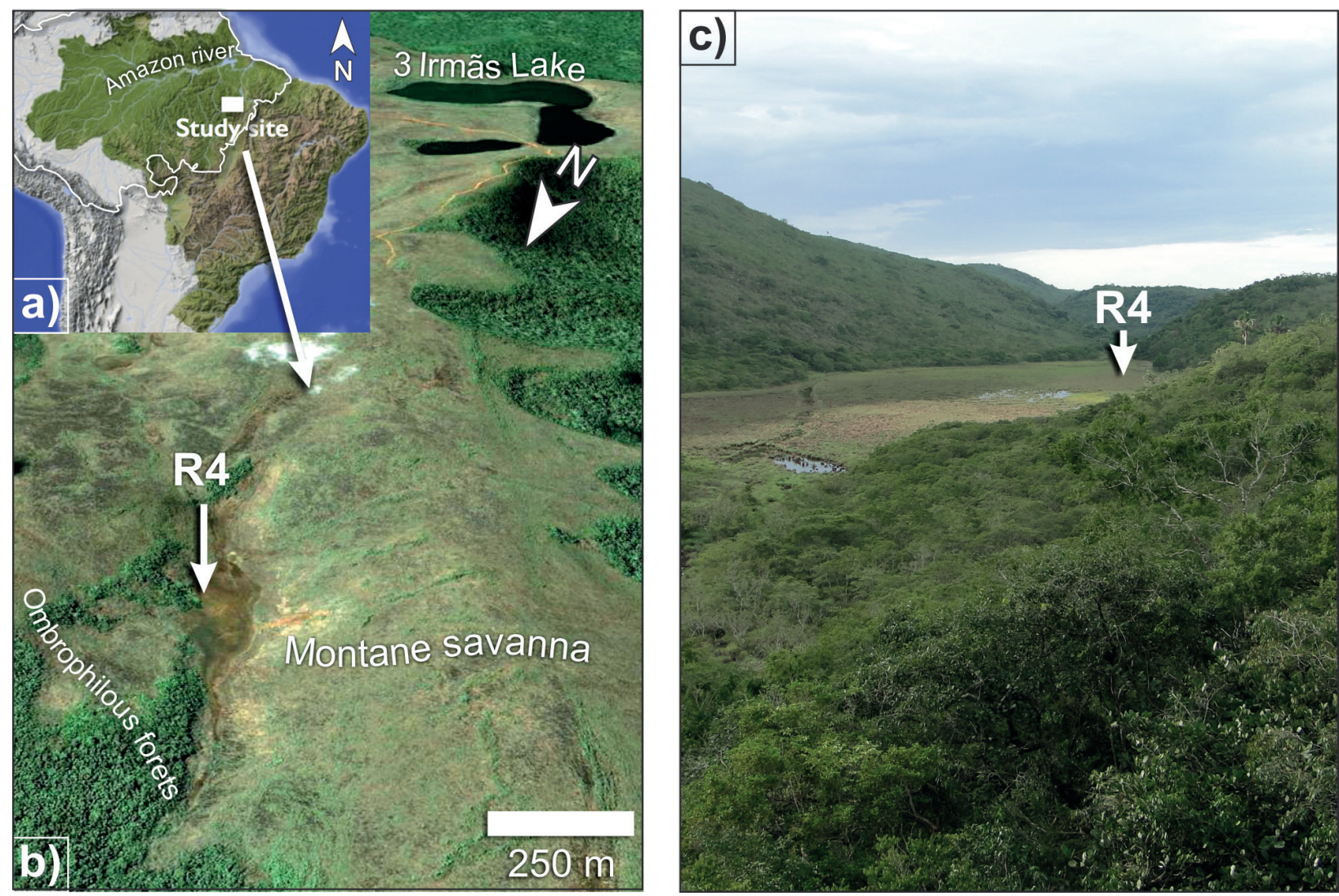

Figure 1 - a) Location of the study site and its position into South America and biogeographic limits of the Amazonia (RAISG 2009). b) Location of the studied Lake (R4 core) in the western portion of the Serra Sul dos Carajás (Source: Google Earth Pro). c) Oblique photography of the studied lake with location of the R4 core.

and hindered the colonization of tree species (Porto and Silva 1989, Skirycz et al. 2014, Nunes et al. 2015). Consequently, small patches of forest (capão de mata) occur along structural features or over different lithologies that are much more sensitive to weathering and lead to the formation of a thicker soil horizon, with higher nutrient and water availability. Palms and macrophytes are the dominant vegetation on the filled lakes.

The regional climate is tropical monsoon, with a mean annual temperature of around $26^{\circ} \mathrm{C}$ (Alvares et al. 2014). Total annual precipitation ranges from 1,800 to $2,300 \mathrm{~mm}$, with a total mean of $\sim 1,550$ $\mathrm{mm}$ during the rainy season (November to May) and $\sim 350 \mathrm{~mm}$ during the dry season (June to October) (Moraes et al. 2005, Sahoo et al. 2016a).

\section{MATERIALS AND METHODS}

A sediment core was collected from a filled lake (R4-95 cm; 06¹9'1.20"S/ 50²7'9.20'W) located in the western part of the Serra Sul de Carajás (Fig. 1b, c) using a Russian Sampler. Core sections were first X-rayed, and then the facies analysis was conducted, including the description of color, lithology, texture and sedimentary structures (Walker 1992). Classification system of lacustrine sediments of the Global Lake Drilling Program was also applied for the core (Schnurrenberger et al. 2001, 2003).

Eight bulk samples of about $2 \mathrm{~g}$ each were used for radiocarbon dating using an Accelerator Mass Spectrometry (AMS) at the Beta Analytic facilities (Miami-FL, USA). Age-depth modelling 
was developed using Bayesian accumulation histories for lake (Guimarães et al. 2016) and peat deposits-Bacon (Blaauw and Christen 2011) in $R$ software (R Development Core Team 2013) with Intcal13.14c calibration dataset (Table I; Reimer et al. 2013).

About $0.2 \mathrm{~g}$ of dried and powdered samples from each sedimentary facies were analyzed by inductively coupled plasma optical emission spectrometry (ICP-OES; major elements) and inductively coupled plasma optical mass spectrometry (ICP-MS; trace elements including REEs), in the Acme Analytical Laboratory (Vancouver, Canada), after tetraborate fusion followed by dilute nitric acid digestion. The analytical error for major and minor elements was within $2 \%$ while for trace elements was within $10 \%$. Total sulphur (TS) and total organic carbon (TOC) were measured using a LECO CS-300 combustion analyzer. Data were statistically analyzed according Sahoo et al. (2015) and Guimarães et al. (2016).

Along the sedimentary facies of the cores, 1 $\mathrm{cm}^{3}$ of sediment was collected at intervals of 2.5-5 $\mathrm{cm}$. A tablet of Lycopodium spores was added to each sample prior to chemical treatments in order to calculate pollen and spore concentration (grains/ $\mathrm{cm}^{3}$ ). All samples were prepared using analytical techniques for the extraction of pollen and spores, including cold hydrofluoric acid and acetolysis (Faegri and Iversen 1989). Pollen and spore counts were made at $x 400$ and $x 1.000$ magnification under a transmitted light optical microscope (Zeiss Axio Imager.M2). The identification of pollen and spores was achieved by comparing their morphological traits with specialized handbooks (Roubik and Moreno 1991, Carreira et al. 1996, Colinvaux et al. 1999), pollen database (Carreira and Barth 2003) and our reference collection (PALINOITV) of Carajás flora. TILIA and TILIAGRAPH software were used for calculations and plotting diagram (Grimm 1987). Precise information about the habitat of plant taxa was achieved from the herbarium database of the Vale mining company and Universidade Federal de Minas Gerais, which present the largest botanical collection of the Serra Sul de Carajás. We also included information from previous studies (Rayol 2006, Nunes 2009, Golder 2010, 2011, Guimarães et al. 2014, in press) and floristic surveys made by us in the studied area and vicinities. The pollen and spore data are presented in diagrams as percentages/concentration of the pollen sum and the pollen taxa. They are grouped into montane savanna, palms, macrophytes, forest formation(capãoflorestal and ombrophilous forest), cold-adapted taxa, pteridophytes, algae and fungi. These data were statistically subdivided into zones of pollen and spore assemblages (palynozones), based on square-root transformations of the percentage data and stratigraphically constrained cluster analysis by the method of total sum of squares using CONISS (Grimm 1987).

Sediment samples (6-50 mg) were also taken at 2.5-5 cm intervals along the sedimentary facies for the isotopic study. The stable carbon and nitrogen isotopes were analyzed in the Centre of Stable Isotope of the Bioscience Institute, São Paulo State University (UNESP), using a CHNS elemental analyzer attached to a Delta $\mathrm{S}$ mass spectrometer (Finnigan MAT), Thermo Scientific ${ }^{\mathrm{TM}}$, Waltham, Massachusetts, EUA, ${ }^{13} \mathrm{C}$ and ${ }^{15} \mathrm{~N}$ results are given with respect to VPDB standard and atmospheric $\mathrm{N}_{2}$, respectively, using the conventional $\delta(\%)$ notation. Analytical precision is $\pm 0.1 \%$ and $\pm 0.2 \%$, respectively. The interpretations about sources of organic matter were based on previous works and references therein (Deines 1980, Salomons and Mook 1981, Meyers 1994, Thornton and McManus 1994, Tyson 1995, Meyers 1994, 1997, 2003, Lamb et al. 2006, Sahoo et al. 2015, 2016b). 


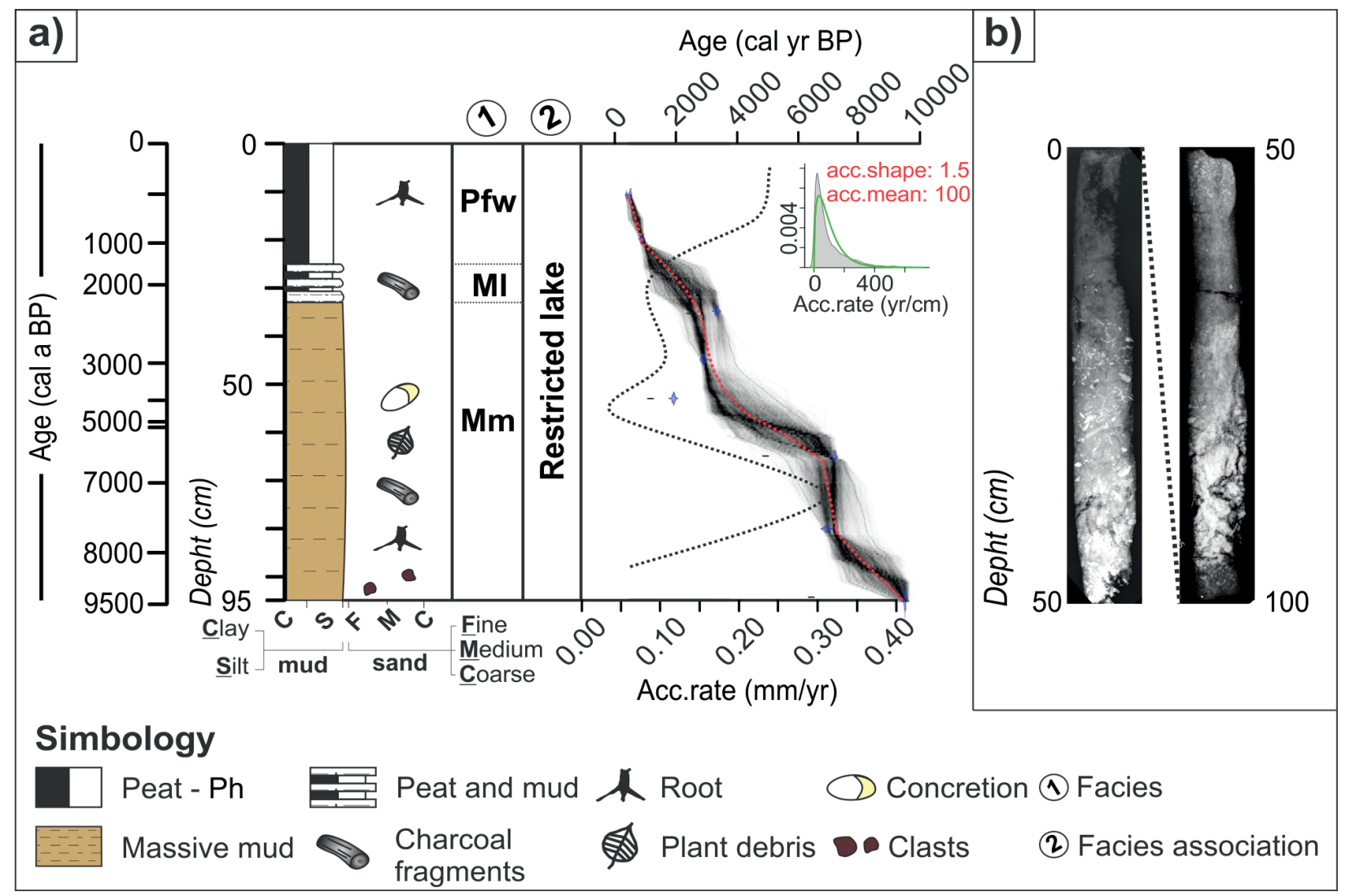

Figure 2 - Lithostratigraphic profiles illustrating facies characteristics and facies succession in R4 core (95 cm) collected from the Serra Sul de Carajás. The profile includes calibrated ${ }^{14} \mathrm{C}$ dates (transparent blue), age-depth model (darker greys indicate more likely calendar ages; grey stippled lines show 95\% confidence intervals; red curve shows single 'best' model based on the weighted mean age for each depth) and sedimentation rates ( $\mathrm{mm} / \mathrm{yr}$ ) along the depth profile based on weighted mean age for each depth. The small box in the upper right corner of each age-depth model: green curve is the accumulation rate (prior) and the grey shading is the modelled accumulation rate (posterior).

TABLE I

Radiocarbon dates (AMS) of the samples from the Serra Sul dos Carajás.

\begin{tabular}{|c|c|c|c|c|c|}
\hline Sample & Lab. code & Material Pretreatment & ${ }^{13} \mathrm{C} /{ }^{12} \mathrm{C}$ & $\begin{array}{l}{ }^{14} \mathrm{C} \text { age } \\
\text { (yr B.P.) }\end{array}$ & 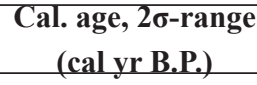 \\
\hline R4-11 & BETA 422171 & organic sediment: acid washes & $-26.0 \%$ & $390 \pm 30$ & $509-427$ \\
\hline R4-20 & BETA 422172 & organic sediment: acid washes & $-26.6 \%$ & $940 \pm 30$ & $924-792$ \\
\hline $\mathrm{R} 4-35$ & BETA 408082 & organic sediment: acid washes & $-26.5 \%$ & $3120 \pm 30$ & $3398-3243$ \\
\hline $\mathrm{R} 4-45$ & BETA 422173 & organic sediment: acid washes & $-26.2 \%$ & $2780 \pm 30$ & $2952-2793$ \\
\hline $\mathrm{R} 4-53$ & BETA 408083 & organic sediment: acid washes & $-25.9 \%$ & $1940 \pm 30$ & $1949-1821$ \\
\hline $\mathrm{R} 4-65$ & BETA 408084 & organic sediment: acid washes & $-24.4 \%$ & $6270 \pm 30$ & $7263-7161$ \\
\hline $\mathrm{R} 4-80$ & BETA 422174 & organic sediment: acid washes & $-25.4 \%$ & $6070 \pm 40$ & $7019-6793$ \\
\hline R4-95 & BETA 408085 & organic sediment: acid washes & $-27.5 \%$ & $8540 \pm 30$ & $9545-9490$ \\
\hline
\end{tabular}


JOSÉ T.F. GUIMARÃES et al.

\section{RESULTS}

\section{AGE MODELLING AND FACIES DESCRIPTION}

Bayesian age-depth modelling for $\mathrm{R} 4$ core assumed a gamma distribution ( accumulation rate of $100 \mathrm{yr} / \mathrm{cm}(0.1 \mathrm{~mm} / \mathrm{yr})$, which resulted in maximum age of deposition of $9500 \mathrm{cal}$ yr BP (Fig. 2; Table I). The 95\% confidence ranges are minimum and maximum at 20 and $61 \mathrm{~cm}$, respectively. The sedimentation rates of the core are between 0.04 and $0.31 \mathrm{~mm} / \mathrm{yr}$, in agreement with rates between 0.02 to $0.69 \mathrm{~mm} / \mathrm{yr}$ described by Sifeddine et al. (2001), Cordeiro et al. (2008), Hermanowski et al. (2012) and Guimarães et al. (2016) in other cores of the Serra dos Carajás. The profile of the sedimentation rates had the highest ( 7000 cal yr BP) and lowest ( 4000 cal yr BP) values in the basal portion of the R4 core. The observed age inversions are probably related to the input of younger organic matter from shallower depths into profundal sediments by root penetration, as described by Guimarães et al. (2016).

Three main sedimentary facies were described in the studied core representing one finning upward cycle of the lake filling (Fig. 2, Table II). The basal portion of the core presents massive mud (facies Mm) deposited from 9500 until 2500 cal yr BP. However, iron oxyhydroxides concretions were observed from 5000 to 3000 cal yr BP (Table II). Mud interbedded with peat (facies Ml) occurred around 2500 until 1500 cal yr BP, which was overlaid by woody peat (facies Pfw) during the last 1500 cal yr BP.

\section{ELEMENTAL GEOCHEMISTRY}

The concentrations of major, trace, and rare earth elements (REEs) in the lake sediments were evaluated using Principal Component Analysis (PCA with varimax rotation). Three principal components $(\mathrm{PC})$ with eigenvalues $>1$ were obtained, which explain $87 \%$ of the total variance
(Fig. 3a). PC 1 (which accounts for $65 \%$ of the total variance) shows high positive loading of major oxides such as $\mathrm{Al}_{2} \mathrm{O}_{3}, \mathrm{TiO}_{2}, \mathrm{Fe}_{2} \mathrm{O}_{3}, \mathrm{P}_{2} \mathrm{O}_{5}$ and trace elements such as Th, U, Zr, Hf, Nb, Y, V, W, $\mathrm{Cr}, \mathrm{Ga}$ and REEs (Cluster-1). All these elements are strongly and positively correlated with $\mathrm{Al}_{2} \mathrm{O}_{3}$ (Supplementary Material, Table SI). This reflects detrital association of these elements and indicates that they derived from the same source, probably catchment lateritic materials transported to the basin. Map of PC1 factor scores show that these components were mainly enriched between 9500 and 2500 cal yr BP associated with facies Mm (Fig. $3 \mathrm{~b}$ ), with a relative decreasing from 7000 until 3000 cal yr BP. Also, PC1 shows high negative loading of TOC, TS, along with $\mathrm{Na}_{2} \mathrm{O}, \mathrm{CaO}, \mathrm{MgO}$, $\mathrm{K}_{2} \mathrm{O}, \mathrm{Hg}, \mathrm{Rb}$, and $\mathrm{Sr}$ (Cluster-2), indicating these components are influenced by organic fractions. However, negative correlations between $\mathrm{Al}_{2} \mathrm{O}_{3}$ and $\mathrm{Ca}-$, Na-, and K-oxides (Table SI) may reflect changes in the rate of weathering that controls the mobility these soluble oxides. High TOC is associated with facies Pfw, being higher after 1500 cal yr BP until the present (Fig. 3b). $\mathrm{SiO}_{2}$ is weakly loaded in both PC-1 and PC-2 and highly positively loaded in $\mathrm{PC} 3$ along with $\mathrm{Sc}, \mathrm{Pb}$ and $\mathrm{Se}$ (Cluster-3). Weak correlation of $\mathrm{SiO}_{2}$ with respect to $\mathrm{Al}_{2} \mathrm{O}_{3}$ and TOC (Table SI) indicates its mixed (detrital and biogenic) origin.

The values of the chemical index of alteration $\left[\mathrm{CIA}=\left(\mathrm{Al}_{2} \mathrm{O}_{3} /\left[\mathrm{Al}_{2} \mathrm{O}_{3}+\mathrm{CaO} *+\mathrm{Na}_{2} \mathrm{O}+\mathrm{K}_{2} \mathrm{O}\right] 100\right)\right]$ have been calculated to infer weathering intensity due to varying degree of water-rock interaction (Nesbitt et al. 1980, Sahoo et al. 2015, Guimarães et al. 2016). The CIA values vary from 91 to 99.6 in core R4, with higher values recorded between 9500 and 2000 cal yr BP associated with Mm facies (Fig. 3c). CIA is positively correlated with $\mathrm{Al}_{2} \mathrm{O}_{3}$, and negatively with $\mathrm{Ca}-, \mathrm{Na}-$, and $\mathrm{K}$-oxides (Fig. $3 \mathrm{c})$. This indicates the breakdown of the primary minerals during weathering that resulted in the loss of mobile elements ( $\mathrm{Mg}, \mathrm{Ca}, \mathrm{Na}$, and $\mathrm{K})$ and 
TABLE II

Facies descriptions and sedimentary processes in the $\mathbf{R} 4$ sediment core.

Facies

Description
Processes
Fragmental woody peat (Pfw)

Massive mud (Mm)
Black peat with root fragments $>10 \mathrm{~cm}$ length and $<0.5 \mathrm{~cm}$ wide. Parts of barks $\sim 0.5 \mathrm{~cm}$. Some leaf remains have 3 to $6 \mathrm{~cm}$ length and $<2 \mathrm{~cm}$ wide.

Grayish brown to olive gray mud interlaminated black peat. Charcoal are present into peat lamina. Some detritic clasts $>1 \mathrm{~cm}$ can also be observed in the transition with facies Mm.

Light olive yellow mud with herbaceous roots with 4 to $10 \mathrm{~cm}$ length and $<5 \mathrm{~mm}$ width. Goethite concretions with 0.5 to $1 \mathrm{~cm}$ are present around $50 \mathrm{~cm}$ depth, filling bark and roots fragments. Subangular lateritic clasts occur in the basal portion.
Predominant reducing conditions under stagnant water conditions, and high contribution of autochthonous organic matter.

Low energy flows with mud inflow from suspension clouds and/or mudflows into the lake basin, followed by short stages of reduced conditions and input of autochthonous and allochthonous organic matter.

Massive nature and basal clasts may be suggestive of fast sediment deposition, which was interrupted by subaerial exposition of the deposit. This may allowed dehydration of ferric hydroxide and oxidation of organic components.

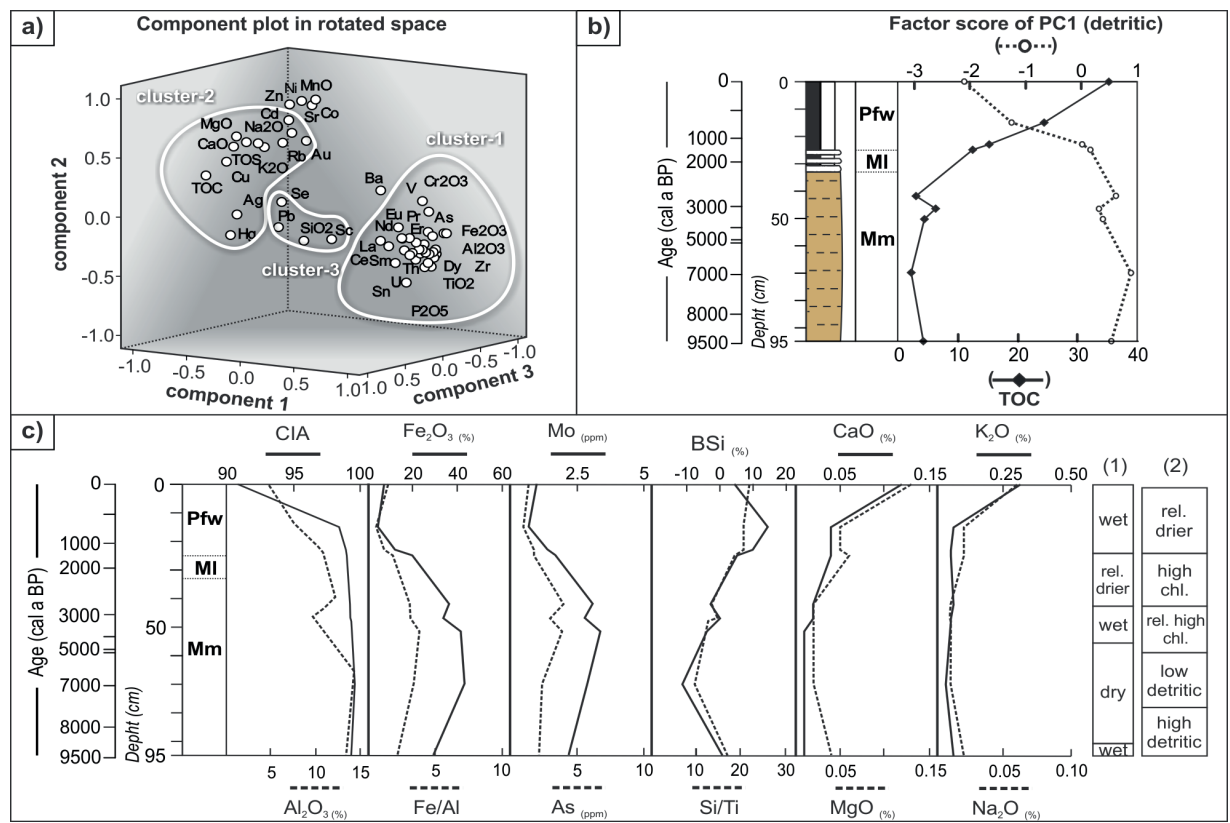

Figure 3 - a) Principal component loading plot of PC1- PC2- PC3 extracted from the Factor Analysis of geochemical components (major and trace elements, and total organic carbon (TOC)) from R4 core; b) factor score of the PC1 and TOC (\%) indicates the distribution of detritic and organic components, respectively along the vertical profile; c) Elemental proxies in the R4 core along the depth profile of the R4 core (for stratigraphic discussion see Fig. 2 and Table II). Paleoclimate records of Carajás lakes described for Serra Sul by (1) Sifeddine et al. (2001), and Serra Norte by (2) Cordeiro et al. (2008). Rel: relatively, Chl: chlorophyll. Considering this last work, high Chl. is related to increased lake levels. 
formation of clay minerals (e.g., kaolinite). $\mathrm{Fe}_{2} \mathrm{O}_{3}$ is also showed similar pattern with $\mathrm{Al}_{2} \mathrm{O}_{3}$ (Fig. $3 c)$. This indicates enrichment of Fe-oxyhydroxide phases (e.g., FeOOH) during chemical weathering, since $\mathrm{Fe}$ is easily enriched in weathering products to form red soils, which become the main source of lake sediments.

In lacustrine environment, $\mathrm{Ti}$ and $\mathrm{Al}$ have been shown to be good markers of the source of the rock. The $\mathrm{Al}_{2} \mathrm{O}_{3} / \mathrm{TiO}_{2}$ ratio is 3-8 for mafic rocks, 8-21 for rocks of mixed composition and 21-70 for felsic rocks. The $\mathrm{Al}_{2} \mathrm{O}_{3} / \mathrm{TiO}_{2}$ ratio in the studied sediment varies from 4.3 to 5.8 , suggesting derivation from mafic rocks. However, the ratio close to the catchment laterites $(6-7.2)$ and soils (4.5) (Sahoo et al. 2015) indicates that the sediments could be simply related to the influence of catchment rocks. Nevertheless, such small variation of the $\mathrm{Al}_{2} \mathrm{O}_{3} / \mathrm{TiO}_{2}(4.3-5.8)$ recorded in the deposition sequence of Lake R4 suggests that the main sources of sediments remained constant along the time. This is further evaluated using geochemical elements such as Al, Ti, Zr, Hf, U, Th, Sc, V, Cr and REEs and their ratios since these elements are useful indicators of sediment provenance due to their relative immobile nature during weathering, transport and sedimentation (Sahoo et al. 2015). The ratios of $\mathrm{La} / \mathrm{Al}, \mathrm{La} / \mathrm{Sc}, \mathrm{Zr} / \mathrm{Hf}, \mathrm{Ti} / \mathrm{Zr}, \mathrm{V} / \mathrm{Cr}, \mathrm{Th} /$ $\mathrm{Sc}, \mathrm{La} / \mathrm{Gd}$ and $\mathrm{La} / \mathrm{Sm}$ (Table $\mathrm{SI}$ ) remained similar in facies $\mathrm{Mm}$ and close to the catchment laterites (LC) (Table SII).

TOC content in sediments is an important proxy for tracking lake productivity and/or high epilimnion temperature (Hodell and Schelske 1998). High TOC was observed after $1500 \mathrm{cal}$ yr $\mathrm{BP}$ until the present (Fig. 3b). High $\mathrm{Ca}$ and $\mathrm{Na}$ in tropical lake sediment are indicative of high leaching of the parent materials in the soils under humid conditions (Enters et al. 2010). The highest values of these elements were noticed at the top of the core. On the other hand, Fe/Al ratio is an indicative of authigenic precipitation of iron oxides
(Lopez et al. 2006) and maximum values of Fe/Al were observed between 5000 and 3000 cal yr BP. The concentrations of biogenic silica (BSi), which expresses the contribution of lacustrine siliceous organisms (e.g., sponges and benthic diatoms) to the total siliceous content, could be used as an indicator of lake productivity and eutrophication of lake (Tallberg et al. 2012). Thus, positive and negative values of BSi indicate presence and absence of biogenic silica, respectivey. BSi (calculated using the following equation: $\mathrm{SiO}_{2}$ $2.8 * \mathrm{Al}_{2} \mathrm{O}_{3}$; Robinson 1994) varies from -12 to 14.6 $\%$, positive values were obtained mainly after 2000 cal yr BP (Fig. 3c). Si/Ti ratio, which is also widely used as an indicator of BSi (Sahoo et al. 2015), shows higher values after 2000 cal yr BP mainly associated with Pfw facies. The concentrations of Fe together with Mo and As can be used as markers of redox condition in surface sediment (Patrick et al. 2014). These elements increased from the base of the core until around $4000 \mathrm{cal}$ yr BP, then suddenly oscillate around $3000 \mathrm{cal}$ yr BP and afterwards decreased. Soluble elements such as $\mathrm{Ca}, \mathrm{Mg}, \mathrm{K}, \mathrm{Na}$ may be used together with organic components to evaluate nutrient input into the lake basin (Sahoo et al. 2015). A significant increase of these elements after $1500 \mathrm{cal}$ yr BP reinforces their affinities with organic matter (Fig. 3c).

\section{PALYNOLOGY}

The summary of the pollen and spore data is presented in Fig. 4, which shows percentages and concentration of the most important taxa and groups, and palynodiversity based on their total sum. Therefore, three palynozones were statically subdivided according to the identification of 45 morphotypes.

The Zone R4-1 (9500-7500 cal yr BP, facies $\mathrm{Mm}$ ) is characterized by the high abundance of montane savanna (max. 95\%, 12,100 grains $/ \mathrm{cm}^{3}$ and 2 sp.), mainly represented by Poaceae (max. 

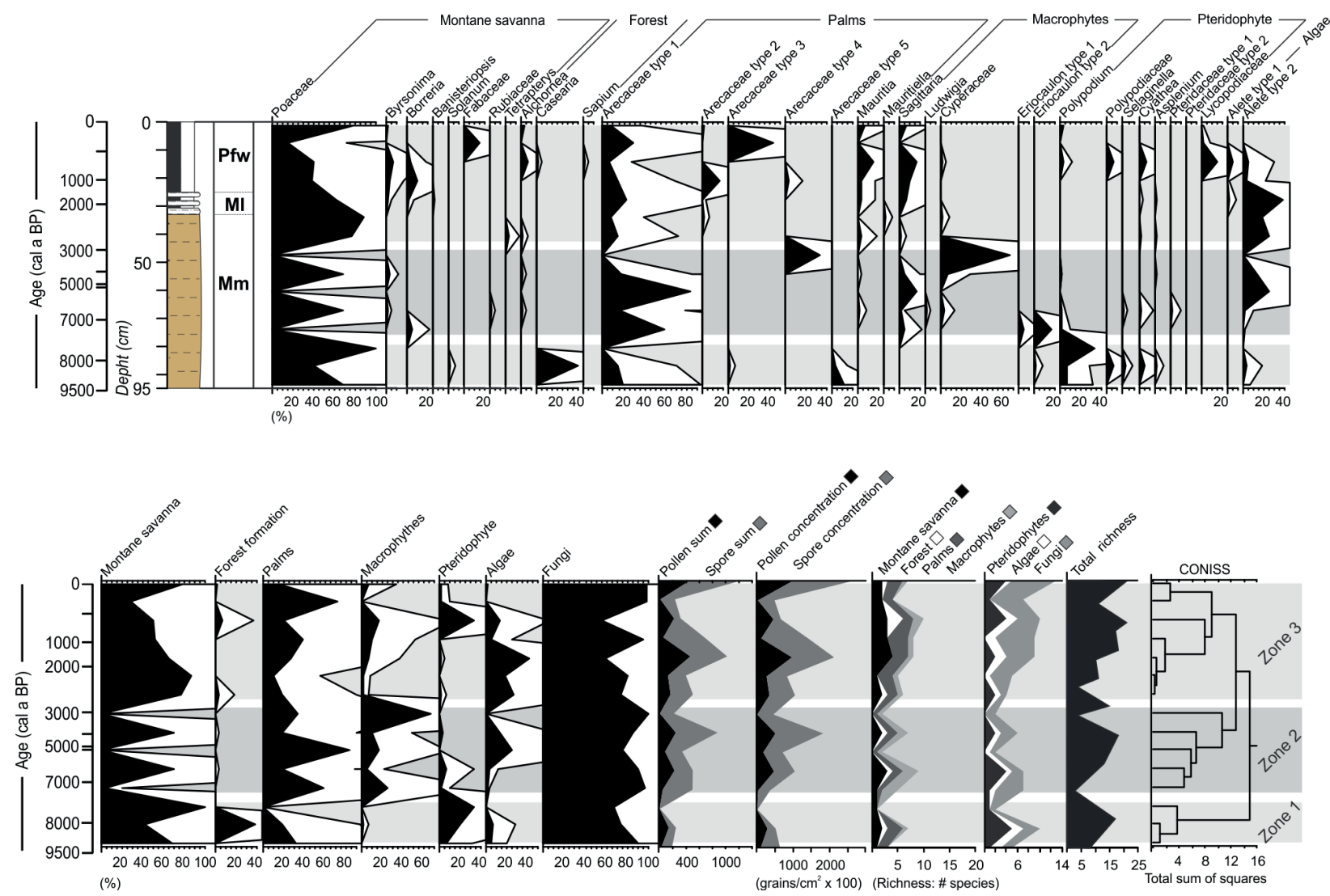

Figure 4 - Pollen diagram of the R4 core with percentages and concentration, as well as palynodiversity values.

$69 \%, 11,600$ grains $\left./ \mathrm{cm}^{3}\right)$. Forest formation taxa (max 50\%, 11,200 grains $/ \mathrm{cm}^{3}$ and $1 \mathrm{sp}$.) also occur with relatively high values, related to Casearia. Subordinately, palms (max. 30\%, 5,400 grains/ $\mathrm{cm}^{3}$ and $3 \mathrm{sp}$.) are represented by Arecaceae type 1 and 5. Pteridophytes (max. 30\%, 4,500 grains/ $\mathrm{cm}^{3}$ and $5 \mathrm{sp}$.) are mainly related to Polypodium and Cyathea (max. $<6 \%, \sim 1200$ grains $/ \mathrm{cm}^{3}$ ). Several sponge spicules and diatom frustules of the Pennales order were also identified in the base of this zone. In general, cold (with heating, overnight) or hot (heating, 5 to $20 \mathrm{~min}$ ) hydrofluoric acid (HF) may be used for palynological analysis (SalgadoLabouriau, 2007), depending on each lab with it wants to have lower influence of acids and heating in the pollen and spore grains. In this work, we used cold HF to try to preserve more grains, since most of the core is detritic. Therefore, silica structures may remain in some portions of detritic facies, as also observed in Guimarães et al. (2014).

The Zone R4-2 (7500-3000 cal yr BP, facies $\mathrm{Mm})$ presents relatively high values of montane savanna (max. 70\%, 33,000 grains $/ \mathrm{cm}^{3}$ and $3 \mathrm{sp}$.), represented by Poaceae (max. 68\%, 32,500 grains/ $\left.\mathrm{cm}^{3}\right)$ and Byrsonima $\left(\sim 1 \%, 500\right.$ grains $\left./ \mathrm{cm}^{3}\right)$. Palms (max. $80 \%, 14,500$ grains $/ \mathrm{cm}^{3}$ and 2 sp.) increase along this zone, with Arecaceae type 1 and Mauritia. Macrophytes occur with high frequencies (max. $25 \%, 3,000$ grains $/ \mathrm{cm}^{3}$ and $3 \mathrm{sp}$.). Forest formation taxa significantly decrease (max 2\%, 400 grains/ $\mathrm{cm}^{3}$ and $1 \mathrm{sp}$ ), as also pteridophytes (max. $10 \%$, 3,000 grains $/ \mathrm{cm}^{3}$ and 4 sp.). Algae (max. 25\%, 13,500 grains $/ \mathrm{cm}^{3}$ ) are mostly represented by only one taxon that seems to bloom in this zone.

The highest pollen and spore frequencies are observed in the Zone R4-3 (3000 cal yr BP until 
the present, facies $\mathrm{Mm}, \mathrm{Ml}$ and $\mathrm{Pfw})$. This is due to montane savanna (max. 90\%, 75,500 grains $/ \mathrm{cm}^{3}$ and $4 \mathrm{sp}$.), mainly represented by Poaceae (max. $80 \%, 75,000$ grains $/ \mathrm{cm}^{3}$ ), Byrsonima (max. 10\%, 3300 grains $/ \mathrm{cm}^{3}$ ) and Borreria (max. 10\%, 1600 grains $/ \mathrm{cm}^{3}$ ). Palms (max. 70\%, 27,000 grains/ $\mathrm{cm}^{3}$ and $4 \mathrm{sp}$.) also occur with high abundance of Arecaceae taxa (max. 43\%, 22,500 grains $/ \mathrm{cm}^{3}$ ) and Mauritia (max. 15\%, 7000 grains $/ \mathrm{cm}^{3}$ ), as well as macrophytes (max. 65\%, 8000 grains $/ \mathrm{cm}^{3}$ and 3 sp.) such as Sagittaria (max. 15\%, 7500 grains/ $\mathrm{cm}^{3}$ ) and Cyperaceae (max. 2\%, 850 grains $/ \mathrm{cm}^{3}$ ). Forest formation $\left(\max 8 \%, 3,500\right.$ grains $/ \mathrm{cm}^{3}$ and 3 sp.) is related to Alchornea (max. 2500 grains/ $\mathrm{cm}^{3}$ ), Casearia and Sapium (max. 2\%, 400 grains/ $\mathrm{cm}^{3}$ ). Algae (max. 40\%, 47,000 grains $/ \mathrm{cm}^{3}$ and 2 sp.) and Pteridophytes (max. 30\%, 7000 grains $/ \mathrm{cm}^{3}$ and $4 \mathrm{sp}$.) also occur in large quantities. The latter are mainly composed by Lycopodiaceae (max. 16\%, 3300 grains $/ \mathrm{cm}^{3}$ ) and Cyathea (max. 8\%, 1600 grains $/ \mathrm{cm}^{3}$ ). Fungi become abundant along this zone following the increase of organic matter contribution from facies Ml to Pfw.

\section{CARBON AND NITROGEN ISOTOPES}

The values of $\delta^{13} \mathrm{C}$ and $\delta^{15} \mathrm{~N}$ range from -25.5 to $-28.6 \%$ o $(\overline{\mathrm{X}}=-27.4 \%$ o $)$ and 2.3 to $4.8 \%$ o $(\overline{\mathrm{X}}=3.6$ $\%$ ), respectively ( $\mathrm{ba})$. This signature generally indicates contribution of $\mathrm{C} 3$ vascular plants $\left(\delta^{13} \mathrm{C}\right.$ from -32 to $-21 \%$, Meyers 1994; $\delta^{15} \mathrm{~N} \sim 0 \%$, Meyers 1997) and macrophytes $\left(\delta^{13} \mathrm{C}\right.$ from -30 to $-25 \%$, Smith et al. $2012 ; \delta^{15} \mathrm{~N}$ from 3 to $6 \%$, Troxler and Richards 2009, Sahoo et al. 2016b) as the predominant source of organic matter in lake sediments. Nevertheless, the values of $\delta^{15} \mathrm{~N}$ are more depleted ( $\overline{\mathrm{X}}=2.4 \%$ ) in facies Mm (Fig. 5b), mainly from around 7000 to $4000 \mathrm{cal}$ yr BP, which suggest partial dilution with terrestrial plants $\left(\delta^{15} \mathrm{~N}\right.$ 10\%, Thornton and McManus 1994).

\section{DISCUSSION}

\section{DEPOSITIONAL PROCESSES OF THE LAKE BASIN}

The studied lake is part of several closed basin lakes of the Serra Sul dos Carajás, which present filling histories marked by alternations between clastic and organic sedimentation grouped into finning and thinning upward cycles as a result of fluctuating shorelines along the late Quaternary. Diagenetic processes such as siderite formation related to abrupt changes in redox conditions of the lakes were also observed (Guimarães et al. 2016).

The R4 Lake is one of the youngest depressions of the Serra Sul dos Carajás with sediment deposition starting around 9500 cal yr BP. However, downcore changes in sedimentary facies, sedimentation rates, major and trace elements and elemental ratios display a strong zonation along the core. Predominance of detrital components values from 9500 to $2500 \mathrm{cal} \mathrm{yr}$ BP suggests high weathering of surrounding catchment rocks and soils, which were deposited in the lake basin under mudflows. High sedimentation rates along with detrital input around $7000 \mathrm{cal}$ yr BP may be also be related to more intense rainfall events. During this period, low BSi and low TOC can be caused by increased mineral matter related to catchment weathering and/or lower internal productivity. Increasing trend of $\mathrm{Fe}$ along with redox-sensitive elements such as As and Mo indicates oxic bottom-water condition (Patrick et al. 2014). Under such conditions, As and Mo are scavenged by Fe-oxyhydroxides. Iron is often enriched at the oxic/anoxic boundaries in the sediment (Thomson et al. 1993). Dissolved $\mathrm{Fe}^{2+}$ diffusing from deeper parts of the sediment is adsorbed on oxyhydroxide surfaces at the redoxboundary. Accentuate enrichment of Fe together with As and Mo at the end of this period indicates the oxic/anoxic boundary in the sediment. The cooccurrence of $\mathrm{Fe} / \mathrm{Al}$ ratio and absence of siderite during this interval indicates less diagenetic 


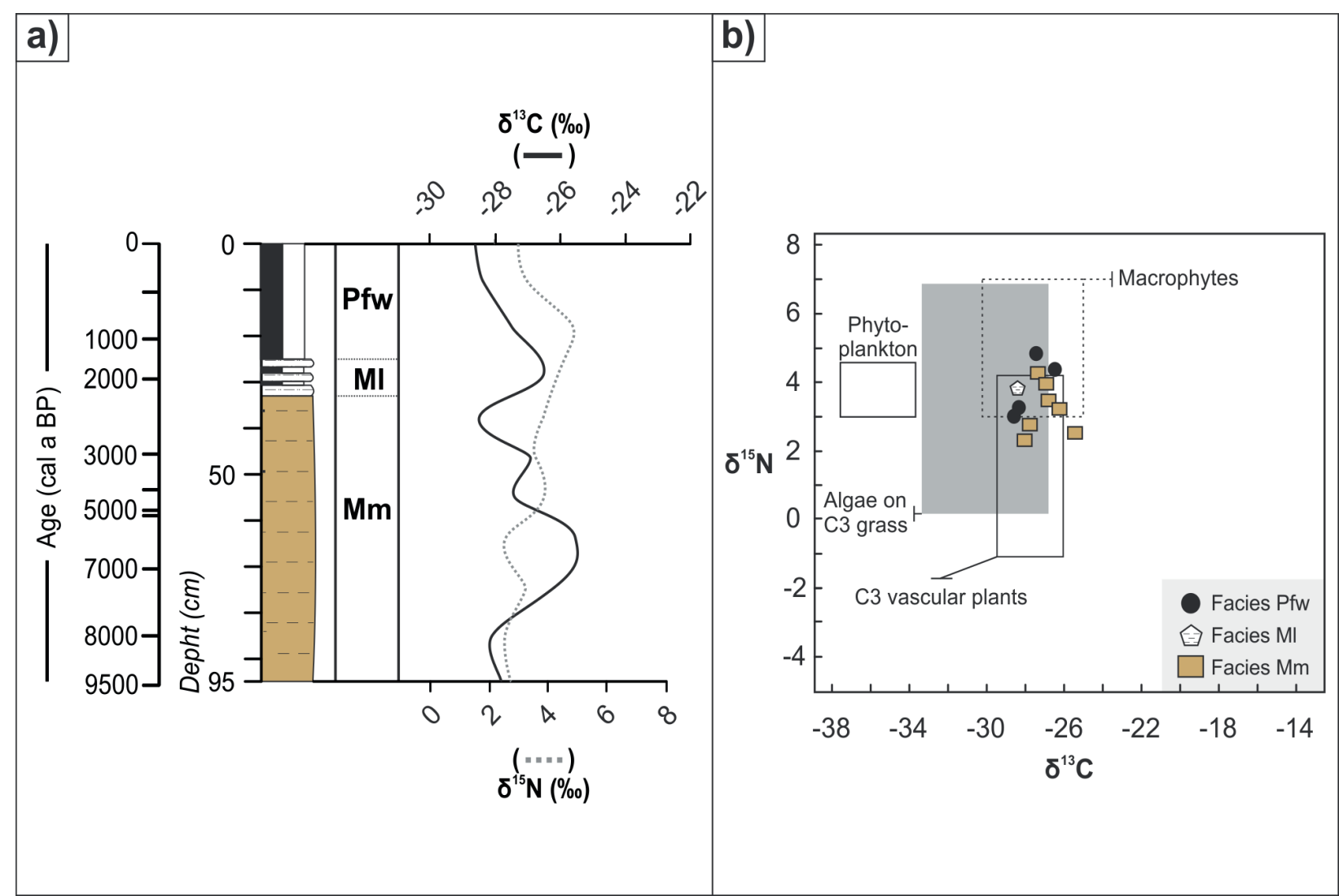

Figure 5 - a) Vertical profiles of the $\delta^{13} \mathrm{C}$ and $\delta^{15} \mathrm{~N}$ values of the $\mathrm{R} 4$ core and b) binary plots of $\delta^{13} \mathrm{C}$ and $\delta^{15} \mathrm{~N}$ based on Hamilton and Lewis (1992) and Sahoo et al. (2015, 2016).

changes due to oxidizing. This is also supported by the decrease of $\delta^{15} \mathrm{~N}$ in the detrital zone.

However, in the period from around 7000 to 3000 cal BP, there was a relative decline of detrital input due to the subaerial exposition of the deposit. During this process, organic components were decomposed leading to mobilization of $\mathrm{Fe}$ and then Fe-oxide precipitation upon oxidation (Chan et al. 2007). This indicates that precipitation-fed runoff to the lake was relatively reduced suggesting that the region was submitted to drier conditions during that period. Although TOC was relatively increased, negative BSi values as well as decrease of Al during this period also suggest drier conditions and low lake levels, which is prevalent at the end of this period. Relatively decrease of Fe together with As and Mo suggests their possible release due to reductive dissolution at or below the sediment water interface.

After 2500 cal yr BP, the detrital components became more restricted to the margins of the lake as a reflection of the decrease in the accommodation space and advance in the filling stage. Thus, until 1500 cal yr BP, only sporadical suspension flows reached the central portion of the lake. However, after $1500 \mathrm{cal}$ yr BP, it occurs the final filling stage of the lake and the deposition of autochthonous organic matter became predominant which suggests high productivity (Hodell and Schelske 1998, Sahoo et al. 2015, Guimarães et al. 2016). The increase of TOC with positive BSi values and high $\mathrm{Si} / \mathrm{Ti}$ ratios during this period is also indicated high lake productivity with autochthonous diatom (Burgess 2007, Sahoo et al. 2015), under relatively humid and wet conditions. This conditions leads 
to eutrophication of the lake (Tallberg et al. 2012), which together with the decrease in the accommodation space, allowed growth of aquatic plants and high decomposition of organic matter in the lake bottom that caused higher sedimentation rate during this period. An increase in $\mathrm{Ca}, \mathrm{Mg}, \mathrm{Na}$ and $\mathrm{K}$ concentrations in sediments indicates higher nutrient contents that support plant growth in the filled lake. High TOC together with low Fe, As, and Mo concentration suggest a reducing condition (Leng et al. 2013), leading to limited bioturbation and bacterial respiration (Demaison and Moore 1980) or rapid burial, accompanied by acidic conditions (Eusterhues et al. 2005).

\section{PALEOVEGETATION DYNAMICS}

The history of vegetation development in the study site using sediments of the R4 Lake started at 9500 cal yr BP. Modern and dominant vegetation types of the western portion of the Serra Sul dos Carajás such montane savanna and forest formation were already established over lateritic crusts and soils, respectively. The co-occurrence of Casearia with Cyathea and Asplenium strongly suggests the presence of ombrophylous forests according to their current distribution and habitat affinity in the study site. In comparison with previous studies (Hermanowsky et al. 2012, Guimarães et al. 2014, in press), the relatively lower abundance of forest taxa as well other groups found in this work may be related to the sediment type, since R4 core is predominately detritic. In addition, faciological, geochemical and isotopic data together with the presence of sponges and diatoms indicates wet environmental condition until around 9500 to 7000 cal yr BP.

From around 7000 to 3000 cal yr BP forest formation and pteridophytes declined, while palms and macrophytes were relatively stable. The lower sedimentation rates and input of detrital components, as well as more depleted nitrogen during this period indicate that the water levels of the lake likely dropped allowing the development of plants adapted to low-stand water and subaerial condition.

After 3000 cal yr until the present, forest formation may have acquired its current structure. The presence of Polypodium, Cyathea and Asplenium reinforce this interpretation. The cooccurrence of Mauritia and Mauritiella with Sagittaria and Cyperaceae are very well-related to the modern condition and the final filling stage of the lake. Decreased accommodation space, high organic carbon with some algae components suggests eutrophic conditions. These proxies clearly indicate wetter environmental and climate conditions prevailing in the study site during this period.

\section{PALEOCLIMATE-DRIVEN ENVIRONMENTAL CHANGES}

The most important feature that affects the climate variability over the Amazon basin has been related with the South American monsoon system (SAMS) (Garreaud et al. 2009, Vera et al. 2006, Marengo et al. 2012). However, it is common to find SAMS conflated with Intertropical Convergence Zone (ITCZ) in several studies about late Quaternary Paleoclimatology (Baker and Fritz 2015), since both present seasonal variability. Actually, SAMS is a product of land-sea thermal gradient. It occurs over the continent and is dependent on land topography, while ITCZ is essentially a permanent oceanic phenomenon affected by annual cycle of insolation and, accordingly, moves around the Equator (Takahashi and Battisti 2007, Vuille et al. 2012).

The seasonal migration of the ITCZ primarily affects coastal areas and northern South America, while SASM develops between September and April and primarily affects southern South America (Garreaud et al. 2009). From September to November, moisture influx from the ITCZ 
contributes to the development of the SASM (Vuille et al. 2012). SASM reaches its maximum during December to February and is characterized by heavy rainfall advancing southward to subtropical latitudes (Flantua et al. 2016).

ITCZ variability may indirectly produce precipitation anomalies along the region where the SAMS is active (Baker and Fritz 2015), since the increase in moisture advection into the Amazon basin may increase the intensity of the SASM, and this is true on modern (e.g. Garcia and Kayano 2014) and ancient ages (millennial timescale) (Baker et al. 2009, Vuille et al. 2012). Thus, a southern shift of ITCZ may produce an intensification of the SASM. However, Cheng et al. (2013) suggested that this shift were related to dry and wet periods in western and eastern Amazonia, respectively, during the mid-Holocene, producing an east-west bipolar see-saw pattern of monsoon precipitation (Cruz et al. 2009).

Prado et al. (2013a, b) presented multiproxy compilation of 120 previously published records of changes in South American paleoclimate covering the mid-Holocene in combination with model simulation. These works proposed a decrease in precipitation over the South Atlantic Convergence Zone (SACZ) area, except for the northeastern Brazil that presented wet conditions. The modern influence of SACZ over eastern Amazonia are welldescribed by Gan and Kousky (1986), Carvalho et al. (2004), Souza and Ambrizzi (2003) and Lopes et al. (2013).

Concurrent changes in weathering process, sediment transport and vegetation types in the Serra Sul dos Carajás, eastern Amazonia, during the Holocene should be intrinsically related to paleoclimate conditions. The drier event observed in this work is well correlated with widespread drying across the southern tropics in the early and midHolocene (e.g. $\sim 6$ to $4 \mathrm{kyr}$ BP by Cross et al. 2000, 8 to $4 \mathrm{kyr}$ BP by Seltzer et al. 2000, 9 to $4.5 \mathrm{kyr}$ BP by Sifeddine et al. 2001, 8 to 4 kyr BP by Mayle and Power 2008, 7.6 to 4.7 kyr BP by Cordeiro et al. 2008, 7.7 to $5.1 \mathrm{kyr}$ BP by Guimarães et al. 2012, 6 kyr BP by Prado et al. 2013b, 7 to $3 \mathrm{kyr}$ BP by Guimarães et al. 2016). According to Prado et al. (2013b), low insolation may be induced a less effective land-sea contrast resulting in less energy available at the surface and diminished ascendant motion. Thus, formation of rain cloud was impaired and drier climate predominated.

\section{CONCLUSIONS}

The information provided in this study based on sedimentary facies, geochemical, pollen, spore, $\delta^{13} \mathrm{C}, \delta^{15} \mathrm{~N}$ and radiocarbon records of the $\mathrm{R} 4$ Lake in the Serra Sul dos Carajás indicated that alternations between high and low detrital and organic matter input into the basin during the last 9500 cal yr BP reflect changes in paleoenvironment and paleoclimate. The period from 9500 to 7000 cal yr BP was marked by high catchment weathering and transport of sediments into the lake under mudflows. Forest and montane savanna were already established over volcanic and lateritic crusts of the study site, respectively. Therefore, wet climate conditions are proposed for that period. Nevertheless, from 7000 to $3000 \mathrm{cal} \mathrm{yr}$ BP, autochthonous process started in the studied lake as detrital input declined and water levels dropped. In response to this drier phase, macrophytes developed in the lake and there is evidence that forest contracted. During the last $3000 \mathrm{cal}$ yr BP, high lake productivity suggests lake becomes eutrophic and forest formation may has acquired its current structure due to the return of wetter climate conditions. These alternations between wetter and drier phases seem to be related to orbital changes influencing the intensity of the SAMS.

\section{ACKNOWLEDGMENTS}

We would like to acknowledge the financial support and field assistance provided by Vale 
Institute of Technology, Conselho Nacional de Desenvolvimento Científico e Tecnológico (CNPq) (479182/2012-4) and PRONEM/FAPESPA/CNPq (069/2014). The first (302839/2016-0) and third author would like to thank $\mathrm{CNPq}$ for research scholarship. The authors thank the members of DIPF, GELIF, DIST, LISF, LAMSF and GABAN of Vale S.A. for the field support and scientific discussions. This project was carried out in the National Forest of Carajás under permission of IBAMA (SISBIO 35594-2).

\section{REFERENCES}

ALVARES CA, STAPE JL, SENTELHAS PC, GONÇALVES JLM AND SPAROVEK G. 2014. Köppen's climate classification map for Brazil. Meteorol Z 22: 711-728.

BAKER P AND FRITZ S. 2015. Nature and causes of Quaternary climate variation of tropical South America. Quatern Sci Rev 124: 31-47.

BAKER PA, FRITZ SC, BURNS SJ, EKDAHL E AND RIGSBY CA. 2009. The nature and origin of decadal to millennial scale climate variability in the southern tropics of South America. In: Vimeux F, Sylvestre F and Khodri M (Eds), Past Climate Variability from the Last Glacial Maximum to the Holocene in South America and Surrounding Regions, New York: Springer, New York, USA, p. 301-322.

BEHLING H AND COSTA ML. 2000. Holocene environmental changes from the Rio Curuá record in the Caxiuanã region, eastern Amazon Basin. Quat Res 53: 369-377.

BERGER AL. 1978. Long-term variations of caloric insolation resulting from the earth's orbital elements. Quat Res 9: 139-167.

BLAAUW M AND CHRISTEN JA. 2011. Flexible palaeoclimate age-depth models using an autoregressive gamma process. Bayesian Anal 6: 457-474.

BURGESS H. 2007. Geochemical indicators of productivity change in Lake Champlain, USA-Canada. Master Thesis, The Faculty of the Graduate College (Geology), University of Vermont, 180 p. (Unpublished).

BUSH MB. 2002. On the interpretation of fossil Poaceae pollen in the lowland humid neotropics. Palaeogeogr Palaeoclim Palaeoecol 177: 5-17.

BUSH MB, SILMAN MR AND LISTOPAD CMCS. 2007. A regional study of Holocene climate change and human occupation in Peruvian Amazonia. J Biogeogr 34: 13421356.
CARREIRA LMM AND BARTH OM. 2003. Atlas de Pólen da vegetação de canga da Serra de Carajás (Pará, Brasil). Belém: Museu Paraense Emílio Goeldi, 112 p.

CARREIRA LMM, DA SILVA MF, LOPES JRC AND NASCIMENTO LAS. 1996. Catalogo de Pólen das Leguminosas da Amazônia Brasileira. Belém: Museu Paraense Emílio Goeldi, 137 p.

CARVALHO LMV, JONES C AND LIEBMANN B. 2004. The South Atlantic Convergence Zone: Intensity, Form, Persistence, and Relationships with Intraseasonal to Interannual Activity and Extreme Rainfall. J Clim 17: 88108.

CHAN MA, ORAM J, PARK AJ, STICH M, SOUZA-EGIPSY V AND KOMATSU G. 2007. Models of iron oxide concretion formation: field, numerical and laboratory comparisons. Geofluids 7: 1-13.

CHENG H, SINHA A, CRUZ FW, WANG X, EDWARDS RL, D'HORTA FM, RIBAS CC, VUILLE M, STOTT LD AND AULER AS. 2013. Climate change patterns in Amazonia and biodiversity. Nat Commun 4: 1411.

COLINVAUX PA, DE OLIVEIRA PE AND PATIÑO JEM. 1999. Amazon Pollen Manual and Atlas - Manual e Atlas Palinológico da Amazônia. Amsterdam: Hardwood Academic, $399 \mathrm{p}$.

CORDEIRO RC, TURCQ B, SUGUIO K, OLIVEIRA DA SILVA A, SIFEDDINE A AND VOLKMER-RIBEIRO C. 2008. Holocene fires in East Amazonia (Carajás), new evidences, chronology and relation with palaeoclimate. Global Planet Change 61: 49-62.

CROSS SL, BAKER PA, SELTZER GO, FRITZ SC AND DUNBAR RB. 2000. A new estimate of the Holocene lowstand level of Lake Titicaca, central Andes, and implications for tropical palaeohydrology. Holocene 10: 21-32.

CRUZ FWJ, BURNS SJ, KARMANN I, SHARP WD, VUILLE M, CARDOSO AO, FERRARI JA, SILVA DIAS PL AND VIANA OJ. 2005. Insolation-driven changes in atmospheric circulation over the past 116,000 years in subtropical Brazil. Nature 434: 63-66.

CRUZ FW, VUILLE M, BURNS SJ, WANG X, CHANG H, WERNER M, EDWARDS RL, KARMANN I, AULER A AND NGUYEN H. 2009. Orbitally driven east-west anti-phasing of South American precipitation. Nat Geosci 2: $210-214$.

DEINES P. 1980. The isotopic composition of reduced organic carbon. In: Fritz P and Fontes JC (Eds), Handbook of Environmental Isotope Geochemistry - The Terrestrial Environment. Amsterdam: Elsevier, p. 329-406.

DEMAISON GJ AND MOORE GT. 1980. Anoxic environments and oil source bed genesis. AAPG Bull-Am Assoc Petr Geol 64: 1179-1209.

ENTERS D, BEHLING H, MAYR C, DUPONT L AND ZOLITSCHKA B. 2010. Holocene environmental 
dynamics of south-eastern Brazil recorded in laminated sediments of Lago Aleixo. J Paleolimno 44: 265-277.

EUSTERHUES K, HEINRICHS H AND SCHNEIDER J. 2005. Geochemical response on redox fluctuations in Holocene lake sediments, Lake Steisslingen, Southern Germany. Chem Geol 222: 1-22.

FAEGRI K AND IVERSEN J. 1989. Textbook of Pollen Analyses, $4^{\text {th }}$ ed., Chichester: J Wiley and Sons, $328 \mathrm{p}$.

FLANTUA SGA ET AL. 2016. Climate variability and human impact in South America during the last 2000 years: synthesis and perspectives from pollen records. Clim Past 12(2): 483-523.

FREITAS HA, PESSENDA LCR, ARAVENA R, GOUVEIA SEM, RIBEIRO AS AND BOULET R. 2001. Late Quaternary vegetation dynamics in the Southern Amazon Basin inferred from carbon isotopes in soil organic matter. Quat Res 55: 39-46.

GAN MA AND KOUSKY VE. 1986. Vórtices ciclônicos da alta troposfera no oceano Atlântico Sul. Rev Bras Meteorol 1: 19-28.

GARCIA SR AND KAYANO MT. 2009. Relação dos sistemas de monção com as variabilidades tropical interanual e multi-decenal. Rev Bras Meteorol 24: 69-86.

GARREAUD RD, VUILLE M, COMPAGNUCCI R AND MARENGO J. 2009. Present-day South American climate. Palaeogeogr Palaeoclim Palaeoecol 281: 180-195.

GRIMM EC. 1990. Tilia e Tiliagraph: PC spreadsheet and graphics software for pollen data. INQUA. Commission for the study of the Holocene, Working Group on DataHandling Methods Newsletter 4: 5-7.

GOLDER. 2010. Diagnóstico ambiental do meio biótico. Volume III-A - Flora. Estudo de Impacto Ambiental, EIA Projeto Ferro Carajás S11D.

GOLDER. 2011. Similaridade das paisagens de savanna metalófila $-3^{\mathrm{a}}$ aproximação. Projeto Área Mínima de Canga.

GRIMM EC. 1987. CONISS: A Fortran 77 program for stratigraphically constrained cluster analysis by the method of incremental sum of squares. Comp Geosciences 13: 13-35.

GUIMARÃES JTF, COHEN MCL, FRANCA MCS, ALVES ICC, SMITH CB, PESSENDA LCR AND BEHLING H. 2013. An integrated approach to relate Holocene climatic, hydrological, morphological and vegetation changes in the southeastern Amazon region. Veget Hist Archaeobot 22: 185-198.

GUIMARÃES JTF, COHEN MCL, PESSENDA LCR, FRANÇA MC, SMITH CB AND NOGUEIRA ACR. 2012. Mid and late Holocene sedimentary process and palaeovegetation changes near the mouth of the Amazon River. Holocene 22: 359-370.

GUIMARÃES JTF ET AL. In press. Modern pollen rain as a background for palaeoenvironmental studies in the
Serra dos Carajás, southeastern Amazonia. Holocene. doi: $10.1177 / 0959683616683260$.

GUIMARÃES JTF, SAHOO PK, SOUZA-FILHO PWM, MAURITY CW, SILVA JUNIOR RO, COSTA FR AND DALL'AGNOL R. 2016. Late Quaternary environmental and climate changes registered in lacustrine sediments of the Serra Sul de Carajás, southeast Amazonia. J Quaternary Sci 31(2): 61-74.

GUIMARÃES JTF ET AL. 2014. Source and distribution of pollen and spores in surface sediments of a plateau lake in south-eastern Amazonia. Quatern Int 352: 181-196.

HERMANOWSKI B, COSTA ML, CARVALHO AT AND BEHLING H. 2012. Palaeoenvironmental dynamics and underlying climatic changes in southeast Amazonia (Serra Sul de Carajás, Brazil) during the late Pleistocene and Holocene. Palaeogeogr Palaeoclim Palaeoecol 365-366: 227-246.

HODELL DA AND SCHELSKE CL. 1998. Production, sedimentation, and isotopic composition of organic matter in Lake Ontario. Limnol Oceanogr 43: 200-214.

KUTZBACH JE, LIU X AND CHEN G. 2008. Simulation of the evolutionary response of global summer monsoons to orbital forcing over the past 280,000 years. Clim Dyn 30: 567-579.

LAMB AL, WILSON GP AND LENG MJ. 2006. A review of coastal palaeoclimate and relative sea-level reconstructions using $\delta^{13} \mathrm{C}$ and $\mathrm{C} / \mathrm{N}$ ratios in organic material. Earth Sci Rev 75: 29-57.

LENG MJ ET AL. 2013. Understanding past climatic and hydrological variability in the Mediterranean from Lake Prespa sediment isotope and geochemical record over the Last Glacial cycle. Quatern Sci Rev 66: 123-136.

LOPES MNG, SOUZA EB AND FERREIRA DBS. 2013. Climatologia da precipitação no Estado do Pará. Rev Bras Clim 12: 84-102.

LOPEZ P, NAVARRO E, MARCE R, ORDOÑEZ L AND ARMENGOL J. 2006. Elemental ratios in sediments as indicators of ecological progresses in Spanish reservoirs. Limnetica 25: 499-512.

MACAMBIRA MJB AND LAFON J-M. 1995. Geocronologia da Província mineral de Carajás: síntese dos dados e novos desafios. Boletim do Museu Paraense Emílio Goeldi, Série Ciências da Terra 7: 263-288.

MARENGO JA ET AL. 2012. Recent developments on the South American monsoon system. Int J Climatol 32: 1-21.

MAURITY CW AND KOTSCHOUBEY B. 1995. Evolução recente da cobertura de alteração no Platô N1- Serra dos Carajás-PA. Degradação, pseudocarstificação, espeleotemas. Boletim do Museu Paraense Emílio Goeldi, Série Ciências da Terra 7: 331-362.

MAYLE FE AND POWER MJ. 2008. Impact of a drier early-mid Holocene climate upon Amazonian forests. 
Philosophical Transactions of the Royal Society B 363: 1829-1838.

MEYERS PA. 1994. Preservation of elemental and isotopic source identification of sedimentary organic matter. Chem Geol 114: 289-302.

MEYERS PA. 1997. Organic geochemical proxies of palaeoceanographic, palaeolimnologic, and palaeoclimatic processes. Org Geochem 27: 213-250.

MEYERS PA. 2003. Application of organic geochemistry to palaeoliminological reconstructions: a summary of examples from the Laurentian Great Lakes. Org Geochem 34: 261-289.

MORAES BC, COSTA JMN, COSTA ACL AND COSTA MH. 2005. Variação espacial e temporal da precipitação no estado do Pará. Acta Amaz 35: 207-214.

NESBITT HW, MARKOVICS G AND PRICE RC. 1980. Chemical processes affecting alkalis and alkaline earths during continental weathering. Geochim Cosmochim Acta 44: 1659-1666.

NUNES JA. 2009. Florística, Estrutura e Relações SoloVegetação em Gradiente Fitofisionômico Sobre Canga, na Serra Sul, Flona de Carajás-Pará. Master Thesis, Universidade Federal de Viçosa, Viçosa 101 p. (Unpublished).

NUNES JA, SCHAEFER CEGR, FERREIRA JÚNIOR WG, NERI AV, CORREA GR AND ENRIGHT NJ. 2015. Soilvegetation relationships on a banded ironstone 'island', Carajás Plateau, Brazilian Eastern Amazonia. An Acad Bras Cienc 87: 2097-2110.

OLSZEWSKI WJ, WIRTH KR, GIBBS AK AND GAUDETTE HE. 1989. The age, origin, and tectonics of the Grão Pará Group and associated rocks, Serra dos Carajás, Brazil: Archean continental vulcanism and rifting. Precambrian Res 42: 229-254.

PATRICK M, ALEXANDER LK, DONATA M, SANJA A, ANNE-CATHRIN W, HENG C, JANIS T, BERNHARD S AND HANS-JURGEN B. 2014. Redox conditions and trace metal cycling in coastal sediments from the maritime Antarctic. Geochim Cosmochim Acta 141: 26-44.

PESSENDA LCR, GOUVEIA SEM, ARAVENA R, GOMES BM, BOULET R AND RIBEIRO AS. $1998 .{ }^{14} \mathrm{C}$ dating and stable carbon isotopes of soil organic matter in forestsavanna boundary areas in southern Brazilian Amazon Region. Radiocarbon 40: 1013-1022.

PORTO ML AND SILVA MFF. 1989. Tipos de vegetação metalófila em áreas da Serra de Carajás e de Minas Gerais, Brasil. Acta Bot Bras 3: 13-21.

PRADO LF, WAINER I AND CHIESSI CM. 2013a. - MidHolocene PMIP3/CMIP5 model results: Intercomparison for the South American Monsoon System. Holocene 23: 1915-1920.
PRADO LF, WAINER I, CHIESSI CM, LEDRU MP AND TURCQ B. 2013b. A mid-Holocene climate reconstruction for eastern South America. Clim Past 9: 2117-2133.

RAISG. 2009. Amazonia 2009. Áreas Protegidas Territorios Indígenas. Red Amazônica de Información Socioambiental Georreferenciada. Available on line: http://raisg. socioambiental.org/system/files/mapaAMAZONIA2009 frente.pdf.

RÄMÖ OT, DALL'AGNOL R, MACAMBIRA MJB, LEITE AAS AND DE OLIVEIRA DC. 2002. 1.88 Ga oxidized A-Type granites of the Rio Maria Region, eastern Amazonian craton, Brazil: Positively Anorogenic! J Geol 110: 603-610.

RAYOL BP. 2006. Análise florística e estrutural da vegetação xerofítica das savannas metalófilas na Floresta Nacional de Carajás; subsídios à conservação. Master Thesis, Universidade Federal Rural da Amazônia e Museu Paraense Emílio Goeldi, Belém, 74 p. (Unpublished).

R DEVELOPMENT CORE TEAM. 2013. R: A language and environment for statistical computing. R Foundation for Statistical Computing, Vienna, Austria. ISBN 3-90005107-0, URL http://www.r-project.org.

REIMER PJ ET AL. 2013. IntCal13 and MARINE13 radiocarbon age calibration curves 0-50000 years cal. BP. Radiocarbon 55(4): 1869-1887.

ROBINSON C. 1994. Lago Grande di Monticchio, southern Italy: a long record of environmental change illustrated by sediment geochemistry. Chem Geol 118: 235-254.

ROUBIK DW AND MORENO JEP. 1991. Pollen and Spores of Barro Colorado Island. St. Louis, Monographs in Systematic Botany 36.

SAHOO PK ET AL. 2016a. Influence of Seasonal Variation on the Hydro-biogeochemical Characteristics of Two Upland Lakes of the southeastern Amazon, Brazil. An Acad Bras Cienc 88: 2211-2227.

SAHOO PK ET AL. 2016b. Geochemistry of upland lacustrine sediments from Serra dos Carajás, Southeastern Amazon, Brazil: implications for catchment weathering, provenance, and sedimentary processes. J South Am Earth Sci 72: 178-190.

SAHOO PK, SOUZA-FILHO PWM, GUIMARÃES JTF, SILVA MS, COSTA FR, MANES CLO, OTI D, SILVA JUNIOR RO AND DALL'AGNOL R. 2015. Use of multiproxy approaches to determine the origin and depositional processes in modern lacustrine sediments: Carajás Plateau, Southeastern Amazon, Brazil. Appl Geochem 52: 130-146.

SALGADO-LABOURIAU ML. 2007. Critérios e técnicas para o Quaternário. São Paulo: Editora Edgard Blücher, $387 \mathrm{p}$.

SALOMONS W AND MOOK WG. 1981. Field observations of the isotopic composition of particulate organic carbon in the southern North Sea and adjacent estuaries. Mar Geol 41: M11-M20. 
SCHNURRENBERGER D, RUSSELL J, KERRY K. 2003. Classification of lacustrine sediments based on sedimentary components. J Paleolimnol 29: 141-154.

SCHNURRENBERGER DW, KELTS KR, JOHNSON TC, SHANE LCK AND ITO E. 2001. National lacustrine core repository (LacCore). J Paleolimnol 25: 123-127.

SELTZER G, RODBELL D AND BURNS S. 2000. Isotopic evidence for late Quaternary climatic change in tropical South America. Geol 28: 35-38.

SIFEDDINE A, MARTIN L, TURCQ B, VOLKMERRIBEIRO C, SOUBIES F, CORDEIRO RC AND SUGUIO K. 2001. Variations of the Amazonian rainforest environment: a sedimentological Record covering 30,000 years. Palaeogeogr Palaeoclim Palaeoecol 168: 221-235.

SKIRYCZ A, CASTILHO A, CHAPARRO C, CARVALHO N, TZOTZOS G AND SIQUEIRA JO. 2014. Canga biodiversity, a matter of mining. Front Plant Sci 5: 1-9.

SMITH CB, COHEN MCL, PESSENDA LCR, FRANÇA MC AND GUIMARÃES JTF. 2012. Holocenic proxies of sedimentary organic matter and the evolution of Lake Arari-Amazon Region. Catena 90: 26-38.

SOUZA EB AND AMBRIZZI T. 2003. Pentad precipitation climatology over Brazil and the associated atmospheric mechanisms. Climanálise - Boletim de Monitoramento e Análise Climática: 1 .

TAKAHASHI K AND BATTISTI DS. 2007. Processes controlling the mean tropical Pacific precipitation pattern. Part I: the Andes and the eastern Pacific ITCZ. J Climate 20: 3434-3451

TALLBERG P, RAIKE A, KUKKARI K, LEIVUORI M, LEHTORANTA J AND PITKANEN H. 2012. Horizontal and vertical distribution of biogenic silica in coastal and profundal of the Gulf of Findland (northeastern Baltic Sea). Boreal Environ Res 17: 347-362.

THOMSON J, HIGGS NC, CROUDACE IW, COLLEY S AND HYDES DJ. 1993. Redox zonation of elements at an oxic/postoxic boundary in deep-sea sediments. Geochim Cosmochim Acta 57: 579-595.
THORNTON SF AND MCMANUS J. 1994. Applications of organic carbon and nitrogen stable isotope and $\mathrm{C} / \mathrm{N}$ ratios as source indicators of organic matter provenance in estuarine systems: evidence from the Tay Estuary, Scotland. Estuar Coast and Shelf Sci 38: 219-233.

TROXLER TG AND RICHARDS JH. 2009. $\delta^{13} \mathrm{C}, \delta^{15} \mathrm{~N}$, carbon, nitrogen and phosphorus as indicators of plant ecophysiology and organic matter pathways in Everglades deep slough, Florida, USA. Aquat Bot 91: 157-165.

TURCQ B, ALBUQUERQUE ALS, CORDEIRO RC, SIFEDDINE A, SIMÕES FILHO F, SOUZA G, ABRÃO JJ, OLIVEIRA FBL, SILVA AO AND CAPITÂNEO JA. 2002. Accumulation of organic carbon in five Brazilian lakes during the Holocene. Sediment Geol 148: 319-342.

TYSON RV. 1995. Sedimentary Organic Matter: Organic Facies and Palynofacies. London: Chapman and Hall.

VERA C ET AL. 2006. Toward a unified view of the American Monsoon Systems. J Climate 19: 4977-5000.

VUILLE M, BURNS SJ, TAYLOR BL, CRUZ FW, BIRD BW, ABBOTT MB, KANNER LC, CHENG H AND NOVELLO VF. 2012. A review of the South American monsoon history as recorded in stable isotopic proxies over the past two millennia. Clim Past 8: 1309-1321.

WALKER RG. 1992. Facies, facies models and modern stratigrahic concepts. In: Walker RG and James NP (Eds), Facies Models - Response to Sea Level Change, 2nd, Ontario: Geological Association of Canada, Ontario, CAN, p. 1-14.

WANG X, AULER AS, EDWARDS RL, CHENG H, ITO E, SOLHEID M. 2006. Interhemispheric anti-phasing of rainfall during the last glacial period. Quat Sci Rev 25: 3391-3403.

\section{SUPPLEMENTARY MATERIAL}

TABLE SI - Correlations among elements.

TABLE SII - Elemental ratios of sediments and LC (Lateritic Crust). 